ISSN : 2087-2461

PENANGGUNG JAWAB Dekan FIKOM

Trimanah, M.Si.

Sekretaris Dekan

Dian Marhaeni K, M.Si

Ketua Penyunting Made Dwi Adnjani, M.Si

Sekretaris

Mubarok, M.Si

Bendahara

Umi Hidayah, S.H.

Dewan Penyunting

Trimanah, M.Si

Edi Ismoyo, M.Si

Suharyoso, S.Sos

Seksi Usaha

Endang Winarsih, S.Sos

Sirkulasi dan Distribusi

Novi, S.Sos

Alamat Redaksi

Fakultas Ilmu Komunikasi

Universitas Islam

Sultan Agung Semarang

Jl. Raya Kaligawe Km. 4

Po. Box 1054/SM

Semarang 50112

Telp. (024) 6583584

ext. $448 / 449$

Fax. (024) 6582455

email : jurnalfikom@yahoo.com
Inovasi Digital Public Relations Pada

Perguruan Tinggi Swasta di Kota Semarang

dalam Meningkatkan Citra

Agus Triyono

agustriyono7@gmail.com

119-126

Eksistensi Buruh Dalam Komunikasi Bipartit

(Upaya Membangun Kemitraan Antara

Buruh dan Pengusaha Secara Ideal di Kota Kretek)

Muhammad Zakki Mubarok

$127-139$

Implementasi Konsep Diri Pada Kelompok Gemes

(Gemuk Menawan Semarang)

Kajian Teoritis Psikologi Komunikasi tentang

Konsep Diri Pada Kelompok Gemes

(Gemuk Menawan Semarang)

Genta Maghvira

140-149

Representasi Perempuan dalam

Film Cinta Suci Zahrana

Urip Mulyadi

$150-158$

Kapitalisme, Budaya Dunia, Internasionalisasi Bahasa dan Nilai-Nilai Islam Pada Tayangan Periklanan Anak di Media Televisi Dalam Perspektif Bidang Kreatif Industri Periklanan

Dian Marhaeni Kurdaningsih

marhaeni@unissula.ac.id

159-172

Paparan Media Promosi Kesehatan

Dengan Pengetahuan Pencegahan Infeksi

Bagi Pengunjung Rumah Sakit

Besar Tirto Husodo

e-mail : besarundip4@gmail.com

Puspa Run Canti

173-177

Model Kampanye Pilkada Atasi Politik Uang

dan Sikap Pesimis Pemilih

(Telaah teoritis dan konsep implementasinya)

Hariyani

nhyani812@gmail.com

178-193 


\title{
MODEL KAMPANYE PILKADA ATASI POLITIK UANG DAN SIKAP PESIMIS PEMILIH (Telaah teoritis dan konsep implementasinya)
}

\author{
Hariyani \\ Mahasiswa Program Studi Magister Ilmu Komunikasi Universitas Diponegoro \\ nhyani812@gmail.com
}

\begin{abstract}
Regarding a number of money politics arises during political campign in Indonesia, it seems eliminating the money politic culture is almost impossible. Since the first election up today, the issue of money politics has always spread every time the election is taking place. According to the author, through the concept of polite political campaigns can resolve money politics issue. A candidate must develop a series of political communication, political marketing and political campaign design using an effective and integrated way to win the election. The outline of political campaign design in this paper aims to resolve the practice of money politics, to restore voter's condifence toward candidates, to foster voters' self-esteem, to cutivate a correct perception that election is not just a momentary celebration, but an honest and clean democracy party. The design of this political campaign is designed to be implemented in districtlevel electoral and can be applied for independent candidates, candidates from political party as well as incumbents candidate.
\end{abstract}

Keywords: money politics, political campaign design, candidate, local election.

Isu mengenai politik uang selalu muncul saat kampanye politik di Indonesia, nampaknya mengeliminasi budaya politik uang hampir tidak mungkin. Sejak pemilihan pertama, isu politik uang selalu menyebar setiap saat pemilihan berlangsung. Menurut penulis, melalui konsep kampanye politik yang santun bisa menyelesaikan masalah money politics. Seorang kandidat harus mengembangkan serangkaian komunikasi politik, perencanaan pemasaran dan kampanye politik dengan menggunakan cara yang efektif dan terpadu untuk memenangkan pemilihan. Garis besar rancangan kampanye politik dalam makalah ini bertujuan untuk menyelesaikan praktik politik uang, untuk mengembalikan kecocokan pemilih terhadap kandidat, untuk mendorong harga diri para pemilih, untuk mengurangi persepsi yang benar bahwa pemilihan bukan hanya sebuah perayaan sesaat, tapi juga jujur. dan partai demokrasi bersih. Rancangan kampanye politik ini dirancang untuk diimplementasikan dalam pemilihan tingkat kabupaten dan dapat diajukan untuk kandidat independen, kandidat dari partai politik dan calon presiden.

Kata kunci: politik uang, desain kampanye politik, kandidat, pemilihan kepala daerah.

\section{Pendahuluan}

Pada pelaksanaan Pemilihan Kepala Daerah Langsung (Pilkada), rakyat menjadi pihak yang paling menentukan siapa calon yang paling layak menjadi pemimpin dalam pemerintahan daerah. Rakyat yang memiliki hak pilih dapat menentukan siapa saja kandidat yang dianggap cakap dan layak berdasarkan pertimbangan-pertimbangan tertentu, seperti platform, visi-misi, program yang diusung kandidat, rekam jejak kandidat, karakteristik kandidat, janji-janji politik kandidat, figur kandidat hingga ideologi partai yang mengusung kandidat.

Pemilihan kepala daerah secara langsung menjadikan suara pemilih sangat menentukan kemenangan kandidat. Oleh karena itu partisipasi pemilih dalam memberikan hak suaranya menjadi sangat penting. Pemilih punya daya tawar yang 
kuat di mata kandidat dan partai pengusung. Sebaliknya bagi kandidat, baik yang berasal dari calon independen, calon yang diusulkan partai politik atau gabungan partai politik, harus mampu menarik hati calon pemilih dan harus mampu mempengaruhi mereka untuk memilih dirinya. Bila kandidat kepala daerah lebih dari satu, maka persaingan antar kepala daerah untuk merebut hati pemilih menjadi sangat tinggi.

Pilkada langsung yang diterapkan sejak tahun 2004, juga membawa fenomena baru dalam alam demokrasi Indonesia yaitu merebaknya money politic atau politik uang, yaitu suatu bentuk pemberian atau janji untuk menyuap seseorang baik supaya orang itu tidak menjalankan haknya untuk memilih atau supaya ia menjalankan haknya dengan cara memilih kandidat tertentu pada saat pemilihan umum. Pemberian bisa berupa uang atau barang. Politik uang umumnya dilakukan oleh simpatisan, kader, atau bahkan pengurus partai politik menjelang hari pencoblosan (Saifullah, 2012). Menurut Yusril, seperti dikutip Ismawan (1999) money politic memengaruhi massa pemilu dengan imbalan materi. Money politic adalah semua tindakan sengaja untuk memberi atau menjanjikan uang atau materi lainnya kepada seseorang supaya ia tidak menggunakan hak pilihnya, memilih peserta pemilu tertentu, atau menggunakan hak pilihnya dengan cara tertentu.

\section{Penyebab Terjadinya Politik Uang}

Beberapa ahli memberikan analisis terkait penyebab terjadinya politik uang, seperti yang dirangkum oleh Taufiq (2014) dalam Studi Kasus Pada Pemilu Legislatif. Penyebab terjadinya politik uang antara lain :

a) Sistem Proporsional Terbuka. Sistem ini dianggap paling ideal, dapat menciptakan iklim kompetisi di antara sesama calon dalam satu partai, dan dianggap lebih demokratis. Hanya calon yang meraih dukungan penuh dari rakyatlah yang dapat duduk di kursi kepemimpinan. Namun sistem ini tidak lepas dari kritik, karena membuka peluang terjadinya praktek politik uang yang justru dianggap tidak mendidik masyarakat dan membuat biaya kampanye mahal (Effendy, 2012).

b) Deideologisasi Politik. Thohari (2014) mengulas tentang asal muasal pergeseran politik ideologi ke politik non-ideologi yang berorientasi pemecahan masalah dan pragmatisme. Menurutnya, dulu untuk menghindari konflik ideologi yang cenderung keras, diberlakukan kebijakan deideologisasi politik, terutama melalui asas tunggal.Deideologi pada perkembangannya bersifat eksesif dan depolitisasi. Partaipartai politik dilarang menonjolkan ideologi dalam setiap kontestasi transisi kekuasaan, apalagi bersifat ideology-oriented, tetapi harus tampil dengan pendekatan program dan penyelesaian masalah.

c) Mental materialisme \& konsumerime semakin kuat. Menurut Firmanzah (2008), politik uang terjadi karena semua elemen yang terlibat dalam urusan politik memandang penting materi. Baik pemilih maupun kontestan sama-sama menekankan aspek materi, sehingga segalanya harus diuangkan dan dijadikan obyek. Semakin mahal dan gemerlap obyek yang dikonsumsi, semakin tinggi nilai individu atau manusia tersebut dalam struktur dan interaksi sosial bermasyarakat.

d) Komunikasi partai politik kepada rakyat sangat minim. Asrinaldi (2014) berpendapat bahwa maraknya politik uang disebabkan pola komunikasi partai politik dengan masyarakat hanya massif pada saat menjelang pemilu saja. Seusai pemilu, masyarakat ditinggalkan begitu saja dan bahkan tidak ada komunikasi sama sekali sehingga masyarakat menjadi alergi dengan ide-ide dan gagasan serta ideologi partai politik. Akibatnya, relasi transaksional (ada uang, ada suara) menjadi satu-satunya pendekatan yang digunakan oleh masyarakat.

e) Politisi menggunakan uang untuk memobilisasi dukungan. Salah satu faktor yang memengaruhi maraknya praktik politik uang adalah calon selalu menggunakan uang untuk memobilisasi pemilih. 
f) Lemahnya regulasi pengelolaan keuangan partai politik. Di Indonesia, pengaturan tentang dana kampanye tertuang dalam UU No. 32 tahun 2004 tentang Pemerintahan Daerah. Dalam UU tersebut memuat pembatasan sumbangan dana pemilu. Namun, menurut Badoh (2010), pengaturannya tidak jelas dan mudah disalahgunakan. Lemahnya regulasi ini ikut menyumbang potensi masuknya dana ilegal kepada calon dan terjadinya politik uang dalam pilkada.

g) Pemilihan dipersepsikan sebagai perayaan. Menurut Sutoro (2004), politik uang terjadi karena kuatnya persepsi bahwa pilkada sebagai perayaan. Semakin maraknya politik uang, membuat sebagian rakyat memandang pilkada bukan sebagai momentum untuk memilih pemimpin yang dapat memperjuangkan kepentingan mereka, namun pilkada dipandang sebagai suatu kesempatan di mana suara rakyat dibutuhkan untuk mengantarkan seseorang menjadi elit politik. Karena itu, mereka merasa berhak mendapatkan upah atas dukungan yang diberikan kepada seorang calon (Susilo dan Hernowo, 2008).

h) Sikap permisif masyarakat pada politik uang. Suburnya politik uang tidak lepas dari cara pandang pemilih yang permisif terhadap politik uang. Masyarakat menganggap sebagai suatu kewajaran dan tidak lagi peka bahwa politik uang secara normatif adalah perilaku yang harus dijauhi (Fitriyah, 2013).

\section{Perilaku Pemilih}

Dilihat dari sudut pandang pemilih, dalam memilih sebuah partai politik maupun kontestan, pemilih memiliki perilaku dalam mengambil keputusan untuk menentukan pilihannya. Menurut Firmanzah (Marketing Politik, 2013), pemilih pada kenyataannya merupakan dimensi yang sangat kompleks. Terkadang perilaku pemilih rasional dan terkadang menjadi non-rasional saat menentukan keputusannya. Perilaku seperti ini menjadikan pemilih memiliki karakter yang berbeda pada setiap pemilihan.

Dalam diri masing-masing pemilih, terdapat dua orientasi sekaligus yaitu; (1) orientasi 'policy-problem-solving', dan (2) orientasi 'ideology'. Ketika pemilih menilai partai politik atau seorang kontestan dari kacamata 'policy-problem solving', yang terpenting bagi mereka adalah sejauh mana para kontestan mampu menawarkan program kerja atas solusi bagi suatu permasalahan yang ada. Pemilih akan cenderung secara objektif memilih partai politik atau kontestan yang memiliki kepekaan terhadap masalah nasional dan kejelasan program kerja. Partai politik atau kontestan yang arah kebijakannya tidak jelas akan cenderung tidak dipilih. Sementara pemilih yang lebih mementingkan ikatan 'ideology' suatu partai atau kontestan, akan lebih menekankan aspek-aspek subjektifitas seperti kedekatan nilai, budaya, agama, moralitas, norma, emosi dan psikografis. Semakin dekat kesamaan partai politik atau calon kontestan, pemilih jenis ini akan cenderung memberikan suaranya ke partai dan kontestan tersebut. Berdasar dua orientasi di atas terdapat konfigurasi pemilih seperti di bawah ini:

Gambar 1. Konfigurasi Pemilih

\begin{tabular}{|c|c|c|}
\hline \multirow{2}{*}{$\begin{array}{c}\text { Tinggi } \\
\text { Orientasi Policy-Problem Solving }\end{array}$} & Pemilih Rasional & Pemilihh Kritis \\
\hline & Pemilih Skeptis & Pemilih Tradisional \\
\hline & & \\
\hline & Rendah & logi Tinggi \\
\hline
\end{tabular}


Firmanzah memetakan tipologi pemilih ke dalam empat kolom, yaitu :

1. Pemilih Rasional.

Punya ciri khas tidak begitu mementingkan ideologi suatu partai atau seorang kontestan. Faktor seperti paham, asalusul, nilai tradisional, budaya, agama, dan psikografis menjadi pertimbangan, tetapi bukan hal yang signifikan. Hal terpenting bagi pemilih jenis ini adalah apa yang bisa (dan yang telah) dilakukan oleh sebuah partai atau seorang kontestan, daripada paham dan nilai partai atau kontestan.

2. Pemilih Kritis

Pemilih jenis ini akan selalu menganalisis kaitan antara sistem nilai partai (ideologi) dengan kebijakan yang akan di buat. Pemilih jenis ini sebaiknya dikelola dengan baik karena memiliki keinginan dan kemampuan untuk memperbaiki kinerja partai. Loyalitas pemilih terhadap partai politik atau seorang kandidat cukup tinggi dan tidak mudah berpaling ke partai atau kandidat lain seperti halnya 'rational voter'.

3. Pemilih Tradisional

Pemilih kategori ini punya orientasi ideologi yang sangat tinggi dan tidak terlalu melihat kebijakan partai politik atau seorang kontestan sebagai suatu yang penting dalam pengambilan keputusan. Biasanya pemilih jenis ini lebih mengutamakan figur dan kepribadian pemimpin, mitos dan nilai historis sebuah partai politik atau seorang kontestan. Pemilih tradisional adalah jenis pemilih yang loyal dan bisa dimobilisasi selama periode kampanye. Pemilih dalam hal ini lebih banyak menggunakan faktor non-rasional dalam proses pengambilan keputusan untuk memberikan suaranya.

4. Pemilih Skeptis

Pemilih skeptis adalah pemilih yang tidak memiliki orientasi ideologi cukup tinggi dengan sebuah partai politik atau seorang kontestan. Keinginan untuk terlibat dalam sebuah partai politik sangat kurang, karena ikatan ideologis mereka memang rendah sekali. Pemilih jenis ini juga kurang memedulikan program kerja atau 'platform' dan kebijakan sebuah partai politik. Dalam aspek tertentu, pemilih jenis ini lebih menonjolkan sikap pragmatisme, misalnya karena politik uang.

Menurut Adman Nursal (2004), perilaku pemilih ditentukan oleh tujuh domain kognitif yang berbeda dan terpisah, sebagai berikut:

a) Issue and policies (isu dan kebijakan publik). Merepresentasikan kebijakan atau program yang diperjuangkan dan dijanjikan oleh partai atau kandidat politik jika kelak menang Pemilu.

b) Social Imagery (Citra Sosial). Citra kandidat dalam pikiran pemilih mengenai 'berada' di dalam kelompok sosial mana atau tergolong sebagai apa sebuah partai atau kandidat politik. Social imagery dapat terjadi berdasarkan banyak faktor, antara lain demografi (usia, gender, agama), sosioekonomi (pekerjaan, pendapatan), kultur dan etnik, serta politis-ideologi.

c) Emotional Feeling (Perasaan emosional). Dimensi emosional yang terpancar dari seorang kontestan atau kandidat yang ditunjukkan oleh kebijakan politik yang ditawarkan.

d) Candidate Personality (kepribadian kandidat). Mengacu pada sifat-sifat pribadi yang penting dan dianggap sebagai karakter kandidat. Beberapa sifat yang termasuk candidate personality antara lain: artikulatif, welas-asih, stabil, energik, jujur, tegar, dan sebagainya.

e) Current event (Peristiwa terkini). Mengacu pada kumpulan peristiwa, isu dan kebijakan yang berkembang menjelang dan selama kampanye.

f) Personal events (peristiwa pribadi), mengacu pada kehidupan pribadi oleh seorang kandidat misalnya skandal seksual, skandal bisnis, menjadi korban rezim tertentu, menjadi tokoh pada perjuangan tertentu, dan sebagainya. $\begin{array}{lrr}\text { g) Epistemic } & \text { Issuees } & \text { (faktor-faktor } \\ \text { epistemik). } & \text { Isu-isu } & \text { pemilihan }\end{array}$ 
yang spesifik yang dapat memicu keingintahuan para pemilih mengenai hal-hal baru. Epistemic issues ini sangat mungkin muncul di tengahtengah ketidak percayaan publik kepada institusi-institusi politik yang menjadi bagian dari sistem yang berjalan.

\section{Landasan Teori}

Supaya pelaksanaan kampanye politik berjalan dengan efektif, maka desain program kampanye perlu direncanakan dengan matang dan terarah. Oleh karena itu dalam merencanakan program kampanye perlu berpedoman pada teori-teori yang telah teruji secara ilmiah. Strategi Kampanye Pilkada dalam tulisan ini, menggabungkan dua pendekatan yaitu menggunakan konsep Political Marketing (Pemasaran Politik) dan Social Marketing (Pemasaran Sosial). Serta berlandaskan pada sejumlah teori yang membahas tentang komunikasi personal, komunikasi politik, pencitraan, perilaku pemilih dan penerapanmodel-model kampanye seperti Model Kampanye Ostegaard, The Five Functional Stages Development Model, dan Model Kampanye Nowak dan Warneyrd.

\section{Marketing Politik}

Secara sederhana marketing politik berarti aplikasi kegiatan marketing di dalam ruang politik yang umumnya terkonsentrasi pada saat pemilu atau pilkada berlangsung. Jika melihat definisi sederhana ini, maka dalam praktiknya pelaksanaan marketing politik bukan hal baru di Indonesia. Menurut O'Shaughnessy, seperti dikutip Firmanzah (2008), marketing politik berbeda dengan marketing komersial. Marketing politik bukanlah konsep untuk 'menjual' partai politik (parpol) atau kandidat kepada pemilih, namun sebuah konsep yang menawarkan bagaimana sebuah parpol atau seorang kandidat dapat membuat program yang berhubungan dengan permasalahan aktual. Di samping itu, marketing politik merupakan sebuah teknik untuk memelihara hubungan dua arah dengan publik.
M. N. Clemente mendefinisikan marketing politik sebagai pemasaran ide-ide dan opini-opini yang berhubungan dengan isu-isu politik atau isu-isu mengenai kandidat. Secara umum, marketing politik dirancang untuk memengaruhi suara pemilih di dalam pemilu.

Menurut A. O'Cass marketing politik adalah analisis, perencanaan, implementasi dan kontrol terhadap politik dan programprogram pemilihan yang dirancang untuk menciptakan, membangun dan memelihara pertukaran hubungan yang menguntungkan antara partai dan pemilih demi tujuan untuk mencapai political marketers objectives.

Menurut Firmanzah, paradigma dari konsep marketing politik adalah; Pertama, Marketing politik lebih dari sekedar komunikasi politik. Kedua, Marketing politik diaplikasikan dalam seluruh proses, tidak hanya terbatas pada kampanye politik, namun juga mencakup bagaimana memformulasikan produk politik melalui pembangunan simbol, image, platform dan program yang ditawarkan. Ketiga, Marketing politik menggunakan konsep marketing secara luas yang meliputi teknik marketing, strategi marketing, teknik publikasi, penawaran ide dan program, desain produk, serta pemrosesan informasi. Keempat, Marketing politik melibatkan banyak disiplin ilmu, terutama sosiologi dan psikologi. Kelima, Marketing politik dapat diterapkan mulai dari pemilu hingga lobby politik di parlemen.

Dari definisi tersebut terkandung pesan bahwa marketing politik dapat menjadi 'teknik' dalam menawarkan dan mempromosikan parpol atau kandidat, menjadikan pemilih sebagai subjek, bukan objek. Menjadikan permasalahan yang dihadapi pemilih sebagai langkah awal dalam penyusunan program kerja. Marketing politik tidak menjamin sebuah kemenangan, tapi menyediakan tools untuk menjaga hubungan dengan pemilih sehingga dari hal itu akan terbangun kepercayaan yang kemudian diperoleh dukungan suara pemilih.

Seperti halnya konsep pemasaran pada umumnya, marketing politik pun mengenal istilah bauran marketing. Konsep 4P (Product, Price, Place, Promotion) dalam marketing 
politik dapat dijelaskan sebagai berikut. Pertama, produk yang dijual dalam konteks marketing politik harus memiliki kualitas yang baik. Begitu halnya dengan kandidat yang dijual ke konstituen harus berkualitas dan otentik. Kedua, price atau harga bukanlah monetary value karena tidak ada biaya yang dikeluarkan oleh konstituen ketika memilih partai atau kandidat tertentu. Price dalam marketing politik lebih ke arah emotional value (nilai emosional) yang diberikan oleh konstituen kepada partai atau kandidat. Emotional value ini bisa berupa personal reason (alasan pribadi) atau personal risk(resiko pribadi). Ketiga, place atau diartikan sebagai distribusi memegang kunci penting dalam pemasaran produk, ketersediaan produk dan sebagainya. Jika diadopsi dalam marketing politik, maka distribusi yang dimaksud adalah channel yang digunakan untuk memasarkan produk politik. Channel dalam marketing politik dapat diartikan tim kampanye yang melakukan kegiatan menyebar luaskan produk politik hingga sampai di tangan konstituen. Keempat, promosi dalam marketing politik mengacu pada upaya-upaya yang dilakukan kandidat untuk mempromosikan diri pada masa kampanye melalui berbagai media.

Uraian tersebut di atas diperkuat dengan penjelasan Nursal (2004), bahwa seorang kandidat harus memiliki produk yang sesuai dengan aspirasi pemilih. Namun harus disadari bahwa produk yang berkualitas tidak begitu saja diminati para pemilih, apalagi di tengah iklim politik uang dan sikap permisif pemilih terhadap politik uang. Agar memudahkan pengenalan, seorang kontestan perlu menciptakan identitas khas dan konsisten berupa : nama, logo, desain visual, tagline, seragam, penampilan, gaya berkomunikasi dan ciri-ciri lainnya sebagai alat identifikasi kontestan tersebut. Dengan kata lain, produk politik diartikan sebagai figur, image, visi-misi dan identitas alat peraga kampanye yang membedakan seorang kontestan dengan kontestan lainnya.

\section{Pemasaran Sosial}

Social Marketing atau dalam bahasa Indonesia disebut dengan pemasaran sosial merupakan suatu adaptasi dari teori-teori pemasaran dalam rangka mendesain suatu program untuk memengaruhi seseorang mengubah perilakunya secara sukarela dalam rangka meningkatkan kesejahteraan individu dan masyarakat di mana individu tersebut menjadi bagian dari masyarakat (Andreassen, 1994). Secara umum social marketing bukan merupakan sains tetapi lebih kepada kegiatan profesional yang bergantung pada beragam disiplin ilmu dalam rangka menciptakan program-program intervensi untuk mengubah perilaku manusia (Smith, 2006). Sebagai bagian dari konsep pemasaran, dalam aplikasinya social marketing juga bergantung pada empat variabel penting pada pemasaran komersial yang sering disebut dengan bauran pemasaran atau markeing mix (Kotler \& Zaltman, 1971) yang meliputi Product (Produk), Price (harga), Place (tempat, distribusi), dan Promotion (Promosi).

Produk yang ditawarkan dalam pemasaran sosial adalah ide, gagasan dan perubahan perilaku (Lefebvre \& Flora, 1988). Seperti halnya pada konsep pemasaran komersial, produk pada pemasaran sosial juga terdiri dari tiga tingkatan yaitu core product atau keuntungan dari perilaku yang ditawarkan, actual product atau perilaku itu sendiri dan augmented product atau produk dan jasa pendukung dari perilaku yang ditawarkan (Kotler \& Lee, 2008).

Sedangkan pengertian price atau harga dalam pemasaran sosial adalah biaya atau pengorbanan yang harus dikeluarkan oleh individu untuk mengadopsi perilaku yang ditawarkan. Kotler \& Lee (2008) menjelaskan bahwa biaya yang dibutuhkan untuk mengadopsi suatu perilaku melingkupi monetary dan non-monetary. Biaya monetary berkaitan dengan biaya yang dikeluarkan untuk membeli produk-produk pendukung yang bersifat tangible. Sedangkan biaya nonmonetary merupakan biaya-biaya seperti halnya waktu, risiko, usaha, energi dan perasaan tidak nyaman ketika mengadopsi perilaku baru.

Place atau diartikan sebagai saluran distribusi yang digunakan oleh pemasar dalam rangka menyampaikan produk yang ditawarkan kepada target audiens (Lefebvre 
\& Flora, 1988). Sedang Promotion (promosi) dalam konteks social marketing haruslah sesuai dengan perilaku yang ingin ditawarkan, harga, saluran distribusi dan kelompok audien yang ingin dituju. Jika promosi dilakukan secara efisien dan tepat, maka programprogram social marketing akan berjalan lebih efektif dan sesuai dengan tujuan.

\section{Model Kampanye Ostegaard}

Model kampanye

Ostergaard dikembangkan oleh Leon Ostergaard. Model ini dianggap paling kental dalam hal sentuhan ilmiahnya dibandingkan dengan berbagai model kampanye yang ada. Hal ini bisa dilihat dari kata-kata kunci yang digunakan di dalamnya seperti kuantifikasi, cause and effect analysis, data dan theoritical evidence. Leon Ostergaard menilai program kampanye untuk perubahan sosial yang tidak didukung oleh temuan-temuan ilmiah tidaklah layak untuk dilaksanakan. Alasannya program semacam itu tidak akan menimbulkan efek apapun dalam menanggulangi masalah sosial yang dihadapi.

\section{Gambar 2. Model Kampanye Ostegaard}

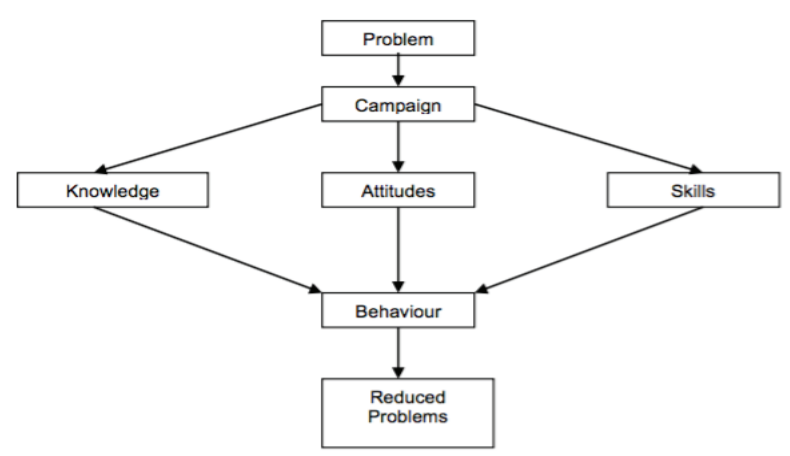

Sumber gambar: Antar Venus, 2004: 15)

Model kampanye Ostergaard memiliki beberapa tahapan dalam penggunaannya. Tahap pertama atau pra-kampanye yaitu mengidentifikasi masalah faktual yang dirasakan dan kemudian dari identifikasi masalah tersebut dicari hubungan sebabakibat (cause and effect relationship) dengan fakta-fakta yang ada.

Tahap kedua, pengelolaan kampanye yang dimulai dari perancangan, pelaksanaan hingga evaluasi. Tahap ini membutuhkan riset untuk mengidentifikasi karakteristik khalayak sasaran untuk dapat merumuskan pesan, aktor kampanye, saluran hingga teknis pelaksanaan kampanye yang sesuai. Pada tahap pengelolaan ini seluruh isi program kampanye diarahkan untuk membekali dan memengaruhi aspek pengetahuan, sikap dan keterampilan khalayak sasaran. Ketiga aspek tersebut dalam literatur ilmiah dipercaya akan memberi pengaruh pada perubahan perilaku. Pada gambar model, terlihat bahwa tanda panah pengetahuan dan keterampilan memengaruhi sikap, baik secara langsung atau tidak langsung, juga memengaruhi perubahan dalam tataran pengetahuan dan keterampilan. Tahap pengelolaan kampanye diakhiri dengan evaluasi tentang efektivitas program yang dilaksanakan. Di sini akan dievaluasi apakah pesan-pesan kampanye sampai pada khayalak, apakah mereka dapat mengingat pesan-pesan tersebut dan apakah mereka dapat menerima isi pesan-pesan tersebut.

Tahap ketiga atau tahap terakhir dari model ini adalah evaluasi pada penanggulangan masalah (reduced problem). Tahap ini disebut juga tahap pasca kampanye. Dalam hal ini evaluasi diarahkan pada keefektifan kampanye dalam menghilangkan atau mengurangi masalah sebagaimana yang telah diidentifikasi pada tahap pra-kampanye.

\section{The Five Functional Stages Development}

Model kampanye ini oleh tim peneliti dan praktisi kampanye di Yale University Amerika Serikat pada awal tahun 1960-an (Larso, 1993) dianggap sebagai model yang paling populer dan banyak diterapkan di berbagai belahan dunia. Model ini populer karena fleksibilitas model untuk diterapkan, baik pada candidate oriented campaigns, product oriented campaigns ataupun ideologically or course oriented campaigns. Fokus pada model ini adalah pada tahap kegiatan kampanye, bukan pada proses pertukaran pesan antara campaigners dengan campaignee. Tahap kegiatan kampanye model ini meliputi identifikasi, legitimasi, partisipasi, penetrasi, dan distribusi. 


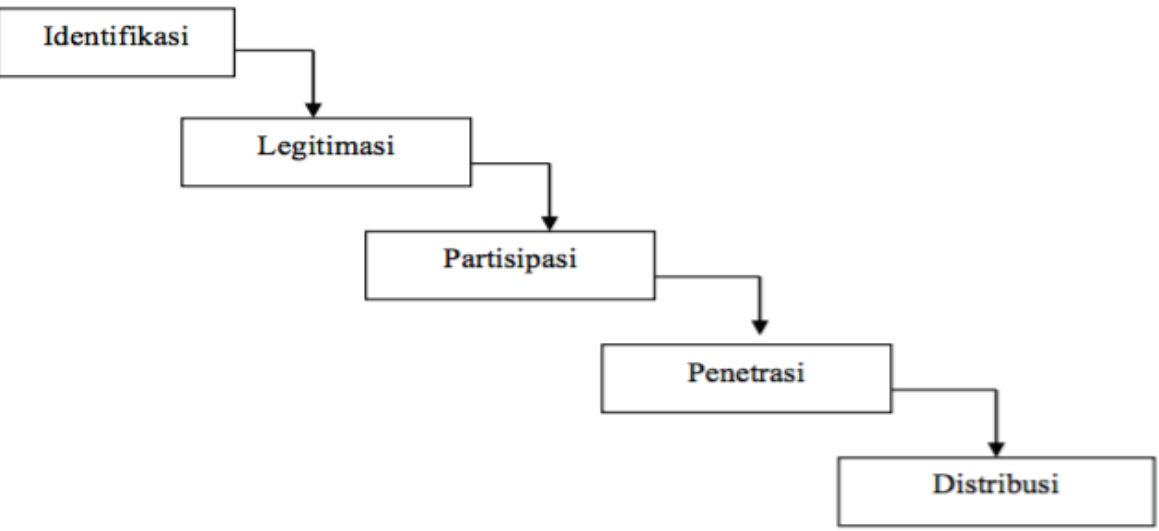

Gambar 2.2. Model Perkembangan Lima Tahap Fungsional

Sumber gambar : Larso, 1993.

Tahap identifikasi merupakan tahap penciptaan identitas kampanye yang mudah dikenali khalayak. Hal-hal yang umum digunakan sebagai identitas kampanye diantaranya simbol, warna, lagu atau jingle, seragam, dan slogan.

Tahap berikutnya adalah tahap legitimasi. Dalam kampanye politik, legitimasi diperoleh ketika seseorang telah masuk dalam daftar kandidat anggota legislatif, atau kandidat kepala daerah yang memperoleh dukungan kuat dalam polling lembaga survei independen. Legitimasi seorang kandidat bisa efektif digunakan dan dipertahankan sejauh kandidat bersangkutan dianggap capable (cakap) dan tidak menyalahgunakan jabatan.

Tahap ketiga adalah partisipasi. Tahap ini dalam prakteknya relatif sulit dibedakan dengan tahap legitimasi karena ketika seorang kandidat, produk atau gagasan mendapatkan legitimasi, pada saat yang sama dukungan yang bersifat partisipasi mengalir dari khalayak. Partisipasi ini bisa bersifat nyata (real) atau simbolik. Partisipasi nyata adanya keterlibatan orang-orang dalam menyebarkan pamflet, brosur atau poster dan ikut berkampanye.

Tahap keempat adalah penetrasi. Pada tahap ini seorang kandidat, sebuah produk atau sebuah gagasan telah hadir dan mendapat tempat di hati masyarakat. Misalnya, seorang kandidat telah berhasil menarik simpati masyarakat dan meyakinkan mereka bahwa ia adalah kandidat terbaik diantara kandidatkandidat yang ada.

Terakhir adalah tahap distribusi atau kita dapat menyebutnya sebagai tahap pembuktian. Pada tahap ini tujuan kampanye pada umumnya telah tercapai.

\section{Model Kampanye Nowak dan Warneryd}

Model kampanye Nowak dan Warneryd merupakan salah satu contoh model kampanye tradisional. Model ini menggambarkan suatu proses unsur-unsur dalam kegiatan kampanye komunikasi, dan punya suatu karakter normatif tertentu yang menawarkan tentang bagaimana kerja secara sistematis dalam melaksanakan kampanye secara efektif. Sistem ini memiliki delapan elemen kampanye yang harus diperhatikan oleh komunikator dalam menjalankan program kampanye, sehingga tujuan kampanye dapat dicapai dengan baik. 
Gambar 4. A Communication Campaign Model

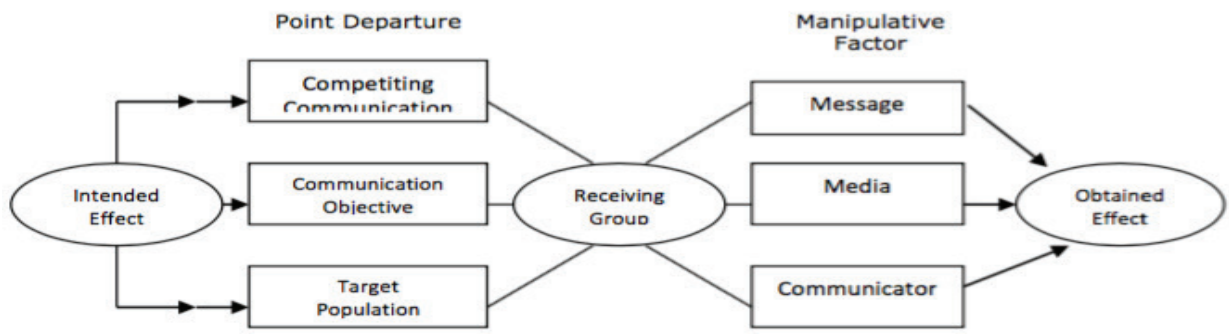

Gambar 2.3. A Communication Campaign Model

(Sumber: Rusady Ruslan, 2002:106)

(Sumber: Rusady Ruslan, 2002:106)

Penjelasan elemen-elemen bagan di atas sebagai berikut :

- The Intended Effect. Efek yang diterapkan dalam suatu kampanye harus dirumuskan dengan jelas dan detail. Dengan cara demikian, penentuan elemen-elemen pendukung pencapaian hasil tersebut akan menjadi lebih mudah dan jelas.

- Competiting Communication. Agar komunikasi kampanye berlangsung efektif dan lancar, maka harus diperkirakan potensi-potensi yang dapat mengganggu kampanye.

- The Communication Object. Kampanye biasanya memiliki tujuan dan tema utama. Setiap keberagaman tujuan kampanye akan berbeda model kampanye komunikasinya. Hal ini harus dipahami oleh juru kampanye tersebut yang akan mengirim pesan kepada penerima.

- Target Population and The Receiving Group. Kelompok penerima adalah bagian dari populasi target. Penyebaran lebih baik ditujukan kepada opinion leader (pemuka pendapat) dari populasi target.

- The Channel. Berbagai bentuk atau jenis saluran komunikasi terkait erat dengan isi pesan, dan segmentasi khalayak sebagai sasaran suatu kampanye. Media massa biasa cocok untuk mengangkat isu atau agenda utama untuk memperoleh tanggapan publik. Sedangkan komunikasi tatap muka (interpersonal) lebih tepat digunakan untuk memengaruhi perilaku masyarakat secara langsung.
- The Message. Pesan-pesan atau tema sentral perlu dikonstruksi dan dibedakan untuk tiap-tiap target audien. Kampanye tahap awal adalah membangun 'awareness' dan pengetahuan bagi khalayak. Tahap selanjutnya bersifat persuasif atau memengaruhi perilaku khalayak sehingga akhirnya dapat mengubah suatu pola tindakan khalayak.

- Communicator or Sender. Komunikator yang terpilih harus memiliki keahlian, kemampuan legitimasi dan kepercayaan serta atraktif di mata khalayaknya. Hal ini sangat penting agar pesan-pesan dalam kampanye lebih diperhatikan publiknya. - Obtained Effect. Efek dari kampanye yang dilancarkan tersebut menghasilkan dampak seperti yang diharapkan atau tidak sesuai harapan, bahkan mungkin bisa memperoleh dampak negatif. Kampanye dapat memengaruhi efek yang bersifat kognisi yaitu berkaitan dengan peningkatan pengetahuan atau perhatian khalayak; bersifat afeksi yaitu berkaitan dengan perasaan senang atau tidak senang atau perubahan sikap negatif menjadi positif; serta bersifat konasi yaitu berkaitan dengan perilaku, aktivitas dan pelaksanaannya baik atau tidak.

\section{Desain Kampanye Pilkada}

Kampanye adalah bagian yang berhubungan erat dengan kegiatan pemilu dan pilkada langsung. Oleh karena itu kampanye harus direncanakan, 
disusun strategi komunikasi dan strategi implementasinya, baik yang menyangkut materi kampanye maupun model kampanye. Dalam Kamus Besar Bahasa Indonesia, strategi diartikan sebagai ilmu dan seni yang menggunakan semua sumber daya bangsa untuk melaksanakan kebijaksanaan terutama dalam hal perang dan damai. Dapat pula diartikan sebagai rencana yang cermat mengenai kegiatan untuk mencapai sasaran khusus. Berpedoman pada teori- teori dan model kampanye yang diuraikan di atas, penulis lalu mengolah dan menyusun sebuah ide atau konsep strategi kampanye yang selanjutnya disebut dengan desain kampanye. Desain kampanye ini ditujukan untuk kampanye pemilihan pemimpin daerah mulai dari tingkat kabupaten/kota hingga provinsi. Bagan berikut ini menggambarkan bagaimana proses kreatif sebuah gagasan atau strategi kampanye pilkada dalam tulisan ini terbentuk.

Bagan 1. Proses Kreatif \& Tujuan Akhir Kampanye

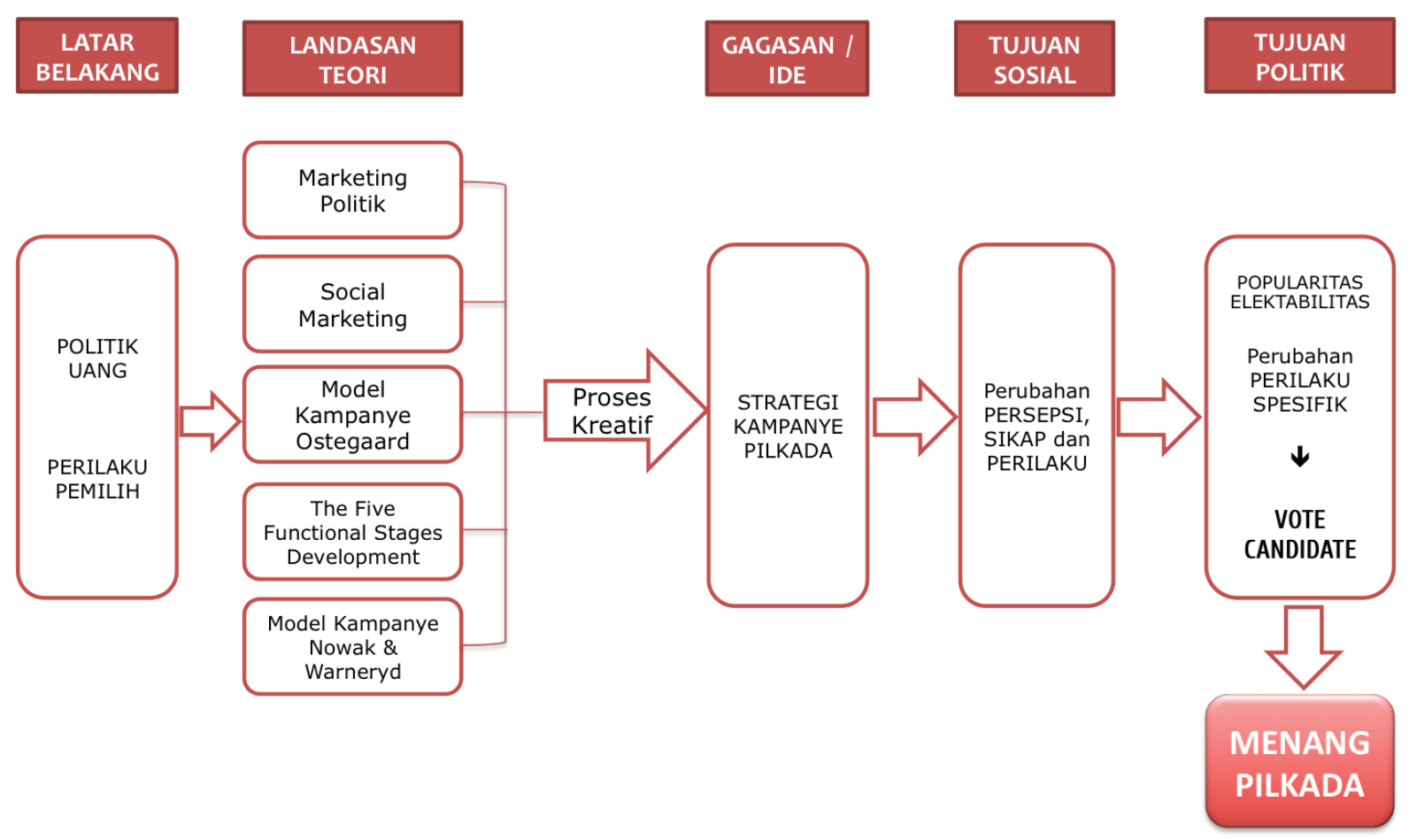

Sumber gambar: pribadi, 2016

Maraknya politik uang dan perilaku pemilih yang berbeda-beda melatar belakangi lahirnya gagasan membuat desain kampanye ini. Selanjunya dengan menggabungkan 5 (lima) teori Marketing Politik, Sosial Marketing, Model Kampanye Ostegaard, The Five Functional Stages Development dan Model kampanye Nowak \& Warneryd, proses kreatif berlangsung hingga menghasilkan Strategi Kampanye Pilkada. Desain kampanye Pilkada ini tentu saja memiliki tujuan sosial dan tujuan politik. Tujuan sosial yang diharapkan ada perubahan persepsi, sikap dan perilaku. Dan tujuan politik yang ingin dicapai adalah kandidat meraih popularitas dan meningkatnya elektabilitas sehingga dapat mengubah perilaku spesifik pemilih, di mana tujuan akhir dari tujuan politik itu sendiri adalah pemilih memberikan suaranya pada kandidat yang bersangkutan. Pada akhirnya, kandidat memperoleh suara terbanyak dan meraih kemenangan dalam Pilkada dengan cara yang santun.

\section{Tahapan Kampanye, Agenda Kerja dan Jangka Waktu}

Penyusunan dan perencanaan strategi kampanye pilkada dalam tulisan ini, secara garis besar terbagi menjadi 4 (empat) 
tahapan kampanye dengan jangka waktu yang dibutuhkan mulai pra-kampanye hingga kampanye pilkada atau tahap 1 hingga tahap 3 membutuhkan waktu minimal 15 bulan kerja.
Sedang tahap 4 atau paska kampanye adalah selama masa jabatan atau sampai tak terhingga waktunya.

\begin{tabular}{|c|c|c|c|}
\hline \multicolumn{2}{|r|}{ TAHAP KAMPANYE } & AGENDA KERJA & JANGKA \\
\hline Tahap 1 & Pra Kampanye & $\begin{array}{ll}- & \text { Identifikasi Permasalahan } \\
- & \text { Riset Karakeristik Masyarakat } \\
- & \text { Perancangan Program Kampanye } \\
- & \text { Desain Brand Image Atribut Kampanye } \\
- & \text { Desain Image dan Pencitraan Kandidat } \\
- & \text { Penyusunan Tim Kampanye } \\
- & \text { Uji Coba Program (Pilot Project) } \\
- & \text { Evaluasi }\end{array}$ & $1-3$ bulan \\
\hline Tahap 2 & Kampanye Politik & $\begin{array}{ll}- & \text { Pelaksanaan Program Regular } \\
- & \text { Pelaksanaan Program Khusus } \\
- & \text { Survei Popularitas dan Elektabilitas } \\
- & \text { Evaluasi }\end{array}$ & $1-12$ bulan \\
\hline Tahap 3 & Kampanye Pilkada/Pemilu & $\begin{array}{ll}- & \text { Pelaksanaan Program Kampanye Pilkada } \\
- & \text { Survei Popularitas dan Elektabilitas } \\
- & \text { Evaluasi } \\
\end{array}$ & 1-3 bulan \\
\hline Tahap 4 & Pasca Kampanye & $\begin{array}{ll}- & \text { Program reguler } \rightarrow \text { Program Kerja } \\
- & \text { Perancangan Program Kerja Baru } \\
- & \text { Evaluasi }\end{array}$ & $\begin{array}{c}\text { Masa Jabatan } \\
5 \text { Tahun }\end{array}$ \\
\hline
\end{tabular}

Masing-masing tahap kampanye memiliki program reguler dan khusus dan setiap program disesuaikan dengan target audien. Tahap-tahap kampanye ini menggambarkan pula adanya perencanaan kampanye yang terstruktur, terarah, dan memiliki jangka waktu pelaksanaan. Sehingga proses perencanaan hingga tahap pelaksanaan kampanye dapat terukur. Biaya yang dikeluarkan untuk setiap pelaksanaan kampanye pun menjadi jelas dan dapat dipertanggung jawabkan.

\section{Produk Sosial Politik}

Dalam konsep pemasaran, produk diartikan sebagai segala sesuatu yang ditawarkan ke pasar untuk mendapatkan perhatian, dibeli, dipergunakan dan yang dapat memuaskan keinginan atau kebutuhan (Kotler \& Armstrong, 1996). Jika dalam komersial marketing, segala sesuatu yang ditawarkan tersebut berupa barang dan jasa, maka dalam konsep kampanye ini yang 'dijual' berwujud produk sosial politik.
Produk sosial politik ini dirancang secara khusus dan lahir dari proses penggabungan konsep marketing politik, social marketing dan konsep-konsep kampanye lainnya seperti yang telah diuraikan di atas. Lahirnya ide produk sosial politik ini juga mempertimbangkan perilaku pemilih. Diberi nama produk sosial politik, karena kata 'sosial' mengacu pada tujuan sosial kampanye ini yaitu mengubah persepsi, sikap dan perilaku pemilih. Tujuan sosial lainnya menciptakan masyarakat di wilayah kabupaten/kota melek internet, mengadakan program-program pemberdayaan masyarakat yang dapat meningkatkan taraf hidup, dan sebagainya. Kata 'politik' mengarah pada kegiatan kampanye politik untuk menaikkan popularitas dan elektabilitas kandidat.

Sosok kandidat pun dikemas dengan dua sisi yaitu secara sosial dan politik. Sisi sosial kandidat, dipoles menjadi sosok yang memiliki kepedulian sosial tinggi dan welasasih. Sedang sebagai sosok politik, kandidat ibaratnya adalah seorang pemimpin suatu 
wilayah yang visioner, bijak, cakap (capable), tegas, down to earth, dan sebagainya. Oleh karena itulah produk pada konsep kampanye ini diberi nama Produk Sosial Politik. Adapun Produk Sosial Politik yang dimaksud, terdiri dari 4 macam, yaitu:

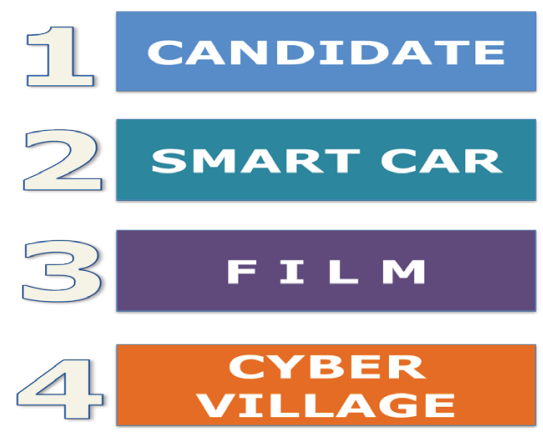

Masing-masing produk sosial politik tersebut memiliki target audien dan program kerja yang sesuai dengan target audien. Produk sosial politik ini tidak bersifat sesaat, atau hanya muncul pada saat masa kampanye politik dan kampanye pilkada berlangsung saja, namun sifatnya berkelanjutan dan renewable (dapat diperbaharui) sesuai dengan perkembangan situasi dan kondisi target audien. Sifat berkelanjutan ini maksudnya produk sosial politik tersebut masih dapat dimanfaatkan atau dijalankan meski masa kampanye telah usai, bahkan dapat menjadi program kerja tetap kandidat terpilih. Atau pada skenario kandidat kalah pilkada sekalipun, produk sosial politik ini, seperti Smart Car, Film dan Cyber Village, masih dapat dijalankan menjadi program business oriented yang memberdayakan potensi daerah dan masyarakat setempat.

\section{Profil Produk Sosial Politik}

\section{Candidate (Kandidat / Calon)}

Kandidat adalah salah satu produk sosial politik yang harus dikelola dengan strategi tertentu agar punya 'nilai jual' tinggi dan bisa diterima masyarakat. Ibarat makanan ringan, maka kemasannya harus dibuat menarik. Demikian pula makanannya, rasanya harus enak bagi setiap orang. Dan produk makanan tersebut memang dicari dan dibutuhkan oleh semua orang. Demikian halnya sosok seorang kandidat, mulai dari penampilan, gaya berkomunikasi, hingga kepribadiannya harus dipoles sedemikian rupa. Sehingga setiap orang mengakuinya sebagai sosok yang punya kepribadian menarik, luwes, cerdas, capable (cakap), visioner dan bisa diterima semua kalangan.

Untuk memasarkan Candidate, tentunya dibutuhkan produk pendamping yang tak kalah pentingnya. Sebagai produk pendamping dalam konsep kampanye ini yaitu : Smart Car, Cyber Village dan Film Pilkada. Ketiga produk sosial politik yang disebutkan terakhir tadi memang dibuat berbeda dengan apa yang selama ini ditemukan di tengah masyarakat. Karena kandidat ingin ditampilkan sebagai 'wajah segar' pada dunia politik. Kandidat akan direpresentasikan sebagai seorang kandidat di luar mainstream dan terlihat sebagai seseorang yang akan melakukan sesuatu yang berbeda dan unik dari tradisi politik melalui produk Smart Car, Cyber Village dan Film Pilkada.

\section{Smart Car (Mobil Pintar)}

Sejenis mobil box yang sisi kirikanan mobil terpasang layar LED berukuran 52 inch. Mobil ini diperlengkapi dengan video player, satu set kamera video untuk syuting terdiri dari camera handheld, GoPro, Drone dan camera CCTV untuk merekam crowds (kerumunan), sekaligus sebagai camera dokumentasi. Selain itu dilengkapi pula dengan mini mixer video-audio, satu set audio, satu set lighting, speaker, X-Box (sejenis Play Station), dan TV monitor mini.

Layar LED berfungsi untuk memutar film, games X-Box dengan permainan yang menyenangkan dan menyehatkan seperti bulutangkis, tenis meja, dan sebagainya. Selain fungsi hiburan, dapat digunakan untuk pendidikan, misal belajar dengan bantuan video yang diadakan diluar ruangan. Fungsi lain, memperoleh pemasukan dari reklame berjalan yang berkeliling kota hingga pedesaan. Saat menggelar sebuah acara, di depan atau samping mobil dapat dipasang mini panggung. Karena memiliki berbagai fungsi inilah mobil dengan layar LED ini dijuluki sebagai Smart Car. 


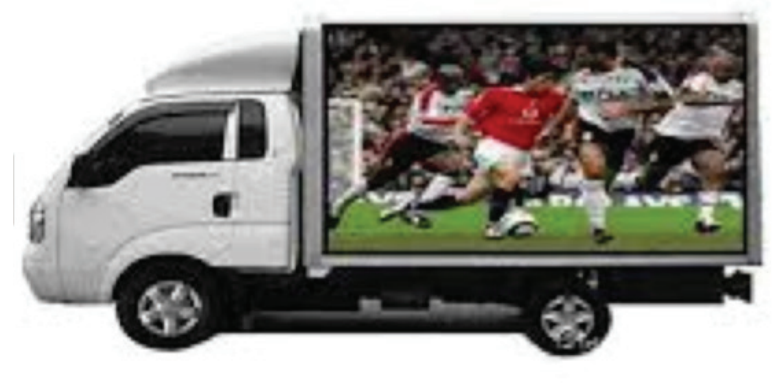

Gambar 3.1. Smart Car

Sumber : pribadi

Sebelum atau selama masa kampanye, Smart Car bisa dijadikan investasi bisnis bagi kandidat. Pemasukan melalui reklame berjalan, sosialisasi program-program pemkab/pemkot dalam bentuk video, bioskop keliling karena biasanya di daerah-daerah tidak ada gedung bioskop, atau disewa untuk pemutaran film saat ada hajatan pernikahan, sunatan, dan sebagainya. Smart Car juga bisa berfungsi sebagai 'layar televisi lokal' dengan kegiatan nonton barengnya (nobar). Smart Car juga berfungsi sebagai alat untuk memobilisasi massa agar berkumpul di tempat mobil tersebut diparkir, misalnya di lapangan.

\section{Film Pilkada Sinopsis Film}

Cerita film ini diangkat dari kisah nyata dibalik pesta demokrasi pilkada. Isi pesan film tujuannya untuk menyadarkan masyarakat dampak buruk dari politik uang. Ada peran antagonis dan protagonis, dan film ini berakhir dengan happy ending. Singkatnya menceritakan tentang seorang Bapak yang mengikuti pilkada karena berambisi menjadi pemimpin. Untuk memenangkan pilkada, ia menggunakan segala cara termasuk politik uang. Pada akhirnya dia menang dan memimpin suatu wilayah. Namun dalam perjalanan kepemimpinannya, ia terpaksa melakukan korupsi untuk mengembalikan biaya yang telah ia keluarkan selama kampanye. Singkatnya, ia dilengserkan oleh masyarakat yang memilihnya walau saat kampanye masyarakat menerima uang dari Bapak tersebut. Pada bagian ini akan dibangun emosi masyarakat karena perbuatan korupsi si Bapak juga dikarenakan andil masyarakat yang mau menerima uang pemberian si Bapak saat kampanye. Karena terbukti korupsi, si Bapak akhirnya dijebloskan ke penjara bersama wakilnya. Digambarkan bagaimana keluarganya menderita setelah si Bapak di penjara. Kisah ini juga menggambarkan, kandidat lain (peran protagonis) yang ikut pemilihan namun sama sekali tidak menggunakan politik uang. Ia memang kalah suara dan tidak terpilih. Namun ia hidup bahagia bahkan bisa berbuat banyak untuk masyarakat tanpa harus menjadi pemimpin. Saat kasus korupsi mencuat, terjadi percakapan antara tokoh ini dengan masyarakat yang menyesal mengapa dulu tidak memilihnya, dan seterusnya.

\section{Isi Pesan Film}

Sarana Film dipilih sebagai salah satu sarana hiburan sekaligus sebagai media paling efektif untuk menyampaikan pesan-pesan perubahan persepsi, sikap dan perilaku masyarakat dalam situasi politik uang melalui jalan cerita atau skenario yang dibuat. Banyak penelitian menemukan bahwa material pendukung seperti ilustrasi dan kejadian bersejarah dalam sebuah pesan sangat memengaruhi perubahan sikap orang yang menerima pesan tersebut. Menurut Koballa (1986) sikap yang terbentuk berdasarkan contoh dan peristiwa bersejarah yang telah terjadi di masa lalu lebih menetap pada diri seseorang dalam waktu yang lama, dibandingkan dengan sikap yang terbentuk berdasarkan data-data. Oleh karena itu diharapkan Film tentang Pilkada ini menjadi semacam ilustrasi kehidupan tokoh pemimpin yang memperoleh jabatannya dengan cara curang dan kisahnya memang diangkat dari kisah nyata atau peristiwa bersejarah. Selama ini masyarakat memang membaca, melihat dan mendengar berita tentang kandidat yang akhirnya dijebloskan ke penjara sekian tahun dan harus mengembalikan uang negara puluhan milyar karena terbukti korupsi, namun hanya sampai disitu, hanya sebatas datadata. Masyarakat tidak mengetahui gambaran kehidupan keluarganya selama kandidat berada di penjara. Bagaimana keluarganya bersusah payah mencari uang untuk menghidupi 
keluarga dan menjual kekayaannya untuk mengembalikan uang negara yang dikorupsi. Film ini mengilustrasikan kehidupan keluarganya tersebut dan bagaimana kehidupan masyarakat usai pesta demokrasi. Bahwa tidak ada perubahan sama sekali di lingkungan masyarakat. Yang miskin tetap saja miskin, lulusan sarjana tetap saja sulit mencari pekerjaan, tidak ada kemajuan pembangunan karena pemimpinnya korup, dan sebagainya. Dalam film ini ada contoh dan peristiwa sejarah yang diangkat, sehingga pesan dalam film diharapkan dapat menetap pada diri seseorang untuk jangka waktu yang lama. isi pesan film juga menyertakan visualisasi mengenai dampak positif dan negatif atas respon tertentu yang muncul dari masyarakat. Karena makin nyata visualisasi pesan, konsekuensinya makin mudah khalayak mengevaluasi pesan tersebut dan makin cepat mereka menentukan sikap untuk menerima atau menolak isi pesan. Jalan cerita film juga melihat pesan dari pendekatan emosional. Disamping himbauan rasa takut, pesan juga dikemas secara kreatif dengan dibumbui hal-hal jenaka yang sifatnya menghibur agar kondisi penonton menjadi rileks dalam menerima pesan-pesan kampanye.

\section{Pendekatan Pemain Utama Film}

Dalam kampanye tidak terlepas dari komunikasi yang bersifat membujuk (persuasif) dan mendidik (edukatif), yaitu berupaya untuk mengubah perilaku, sikap, tanggapan, persepsi, hingga membentuk opini publik yang positif dan mendukung atau yang menguntungkan dari segi citra dan sebagainya. Pemain utama dalam film ini berperan sebagai komunikator utama. Komunikator adalah orang yang mampu menjelaskan atau menyampaikan suatu kegiatan dan program kerja kepada publiknya sekaligus sebagai perwakilan bagi organisasi maupun lembaga (Ruslan, 2008 p:28). Demikian pula dengan pemain utama atau aktor utama dalam film ini punya peran menyampaikan pesan-pesan utama kampanye.

Secara umum pelaku kampanye adalah siapapun yang terlibat dalam menggagas, merancang, mengorganisasikan, dan menyampaikan pesan dalam sebuah kegiatan kampanye. Namun pelaku kampanye yang dimaksud di sini adalah sumber pesan atau penyampai pesan yang secara langsung berkomunikasi dengan publik/khalayaknya (Venus, 2009, p. 54). Oleh karena itu, pemeran utama dalam film ini adalah aktor dan aktris film kenamaan sebagai daya tarik, namun juga memiliki kredibilitas sebagai komunikator dengan memenuhi aspek-aspek keterpercayaan, keahlian, daya tarik dan faktor pendukung lainnya, seperti dijelaskan dalam tabel berikut.

Tabel 4. Kredibilitas Komunikator (Sumber : Venus, 2009)

\begin{tabular}{|c|c|}
\hline ASPEK & KARAKTERISTIK \\
\hline Keterpercayaan & $\begin{array}{l}\text { Berkaitan dengan } \\
\text { moral (bukan soal } \\
\text { kemampuan), } \\
\text { kejujuran, ketulusan, } \\
\text { dan adil, memiliki } \\
\text { sikap dan perilaku } \\
\text { terpuji, kepedulian dan } \\
\text { tanggung jawab sosial, } \\
\text { serta integritas pribadi. }\end{array}$ \\
\hline Keahlian & $\begin{array}{l}\text { Tingkat pendidikan, } \\
\text { kecerdasan, wawasan } \\
\text { yang luas, penguasaan } \\
\text { keterampilan, dan } \\
\text { pengalaman. }\end{array}$ \\
\hline Daya Tarik & $\begin{array}{l}\text { Fisik: penampilan } \\
\text { seseorang memengaruhi } \\
\text { bagaimana khalayak } \\
\text { memersepsikan } \\
\text { narasumber. } \\
\text { Psikologis : kesamaan } \\
\text { dengan penerima pesan } \\
\text { yaitu kemiripan yang } \\
\text { membuat orang-orang } \\
\text { lebih percaya jika } \\
\text { pembicara memiliki } \\
\text { kemiripan dengan kita. }\end{array}$ \\
\hline $\begin{array}{l}\text { Faktor Pendukung } \\
\text { lainnya }\end{array}$ & $\begin{array}{l}\text { Keterbukaan, } \\
\text { ketenangan dan } \\
\text { kemampuan } \\
\text { bersosialisasi yang } \\
\text { mempermudah } \\
\text { pendekatan dengan } \\
\text { audience. }\end{array}$ \\
\hline
\end{tabular}




\section{Pendekatan Pemeran Pembantu Film}

Sebagian pemain film melibatkan kelompok rujukan di masyarakat sebagai pemeran pembantu. Para peneliti di Ontario, Canada (Kotker, 1995) mengemukakan bahwa pendekatan kelompok rujukan menjadikan isi pesan lebih efektif. Pemeran pembantu film ini, misalnya diambil dari tokoh-tokoh masyarakat atau yang berasal dari kelompok rujukan di masyarakat. Kelompok rujukan adalah sekumpulan orang yang memberikan inspirasi tertentu pada orang lain dan mereka menjadi panutan atau model untuk dicontoh. Pesan kampanye akan lebih efektif bila memperlihatkan orang-orang yang menjadi rujukan bagi orang lain. Seseorang akan lebih mudah menerima isi pesan jika orang lain yang menjadi rujukannya juga menerima pesan tersebut. Dengan pendekatan kelompok rujukan yang ikut menjadi pemain dalam film tersebut, diharapkan masyarakat yang menonton film ini merasa seolah-olah nyata, sehingga akan mudah mencontoh sikap dan perilaku yang ditunjukkan kelompok rujukan tersebut melalui perannya dalam film.

Masyarakat setempat pun ikut dilibatkan sebagai figuran. Film ini bercerita tentang pelaksanaan pilkada sehingga terdapat adegan kolosal yang memerlukan banyak figuran. Masyarakat biasa dilibatkan sebagai figuran sekaligus bagian dari salah satu teknik kampanye partisipasi, yaitu teknik yang mengikutsertakan atau peran serta audien untuk memancing minat atau perhatian yang sama ke dalam suatu kegiatan kampanye dengan tujuan untuk menumbuhkan saling pengertian, menghargai, kerjasama dan toleransi. Masyarakat yang dilibatkan secara simbolis maupun praktis, akan mempermudah tercapainya tujuan kampanye.

Mereka yang terlibat sebagai pemeran pembantu maupun figuran, tentunya akan mendapat imbalan jasa atas hasil kerjanya dengan nominal sesuai peran masing-masing. Di sinilah kunci mengatasi politik uang dalam kampanye, seperti yang akan diuraikan pada bab selanjutnya tentang tujuan kampanye. Dalam politik uang, masyarakat menerima uang dengan cuma-cuma dan ajakan untuk memilih kandidat tertentu. Dalam konsep kampanye tulisan ini, politik uang diubah menjadi do something first, then get reward (get paid). Lakukan sesuatu lebih dulu, akan mendapat bayaran kemudian.

\section{Sarana Mobilisasi Massa}

Pemutaran Film dengan model layar tancap adalah sarana efektif untuk memobilisasi massa di suatu tempat, sekaligus menghidupkan ekonomi desa. Biasanya di arena layar tancap, dipenuhi pedagang kaki lima. Demikian pula Film Pilkada ini nantinya akan diputar dengan format nonton bareng bersama kandidat, menggunakan layar LED pada Smart Car. Selain menonton film, digelar pula kuis berhadiah souvenir.

\section{Cyber Village (Desa Siber)}

Cyber Village ini adalah suatu konsep internet mandiri di lingkungan kelurahan/desa yang dapat diakses tanpa biaya oleh warga setempat selama 24 jam dengan fasilitas free Wi-Fi. Memanfaatkan salah satu ruangan kantor kelurahan atau membangun ruangan sendiri dengan teras yang luas, sehingga bisa menampung sejumlah orang. Jangkauan sinyal Wi-Fi bisa sejauh 15 kilometer atau hanya sejauh 1 kilometer dengan bandwith mencapai 100 Megabyte. Sehingga saat diakses lebih dari 50 orang secara bersamaan, jaringan tidak lambat. Jaringan internet diperoleh dengan cara bekerjasama dengan operator telekomunikasi yang ada atau membangun jaringan internet lokal sendiri, sesuai dengan regulasi yang berlaku.

Internet mandiri ini punya kelebihan banyak karena situs-situs yang tidak dikehendaki dapat diblokir secara mandiri. Selain itu, dapat dimanfaatkan untuk kegiatan e-administrasi di lingkungan desa. Penempatan Wi-Fi di ruang tersendiri menyatu dengan kompleks kantor kelurahan bisa menjadi tempat berkumpulnya warga desa. Berbagai kegiatan yang berbasis teknologi internet seperti belajar jarak jauh, atau pelatihan berselancar dengan internet, dapat diadakan untuk meningkatkan kapasitas dan kapabilitas warga desa. 
Pada konsep Cyber Village ini, misalnya: memberdayakan ibu-ibu rumah tangga untuk memproduksi panganan atau snack yang tahan lama, sehingga bisa dijual secara online. Sebelumnya, para ibu mendapat pelatihan terlebih dahulu bagaimana memproduksi jajanan yang sehat, higienis dan memiliki kemasan menarik. Pelatihan membuat panganan difasilitasi oleh investor atau kandidat. Tidak ada batasan usia atau jumlah ibu yang ikut serta. Siapa saja selama merasa mampu, bisa berperan aktif. Dengan cara demikian roda perekonomian di desa berputar. Dengan fasilitas internet, jajanan dari desa tersebut dapat dijual secara online. Untuk mengelola online shop dapat memberdayakan pemuda Karang Taruna. Investor juga membantu distribusi jajanan tersebut ke daerah-daerah lain. Promosi pun dapat dilakukan dengan memanfaatkan media sosial yang dikelola oleh pemuda-pemudi Karang Taruna. Dengan sendirinya akan memperoleh popularitas atas keberhasilan mengimplementasikan program, bahkan dikenal luas hingga ke wilayah lain.

Dan untuk memberikan rasa bangga bahwa di desa mereka dijadikan sebagai sentra jajanan, di tempat tertentu atau di gerbang desa bisa menempatkan ambient media. Pihak kelurahan dapat melakukan monetisasi ambient media ini. Misalnya, saat kampanye pemilu, kandidat dapat menyewa 'layar' ambient media untuk memasang poster dan uang sewa masuk kas desa. Pengalaman baru dan berbeda ini, tentu akan mudah diingat oleh warga desa.

\section{Program Kerja , Target Audien, dan Tolok Ukur Keberhasilan.}

Masing-masing produk politik tersebut memiliki program kerja dan jangka waktu yang jelas. Jangka waktu terdiri dari 4 tahap meliputi pra kampanye, kampanye politik, kampanye pilkada dan pasca kampanye. Dan setiap program kerja pada masing-masing tahapan waktu menyasar target audien tertentu sehingga program kerja yang diterapkan dapat berjalan efektif. Demikian pula setiap program kerja memiliki tolok ukur keberhasilan untuk menilai tingkat keberhasilan program kerja setelah implementasi di lapangan.

\section{DAFTAR PUSTAKA}

Nursal, Adnan. 2004. Political Marketing : Strategi Memenangkan Pemilu, Sebuah Pendekatan Baru Kampanye Pemilihan DPR, DPD, Presiden. Jakarta : Gramedia Pustaka Utama.

Firmanzah. 2013. Marketing Politik : Antara Pemahaman dan Realitas. Jakarta : Yayasan $\boldsymbol{.}$

Indikator Politik Indonesia. 2013. Survey : Sikap dan Perilaku Pemilih Terhadap Politik Uang.

Pilkada Studi Center. 2014. Telaah Pilkada : Perilaku Pemilih di Indonesia.

Transkrip Diskusi Publik Terbatas "Politik Uang Dalam Pilkada", Hotel Acacia Jakarta, 30 Juni 2005 (diunduh dari ijrsh.files.wordpress.com/2008/06/ politik-uang-dalam- pilkada.pdf, 24 Desember 2011)

http://pksjateng.or.id/index.php/read/news/ indeks/kabar_pemilu tentang pilkada diakses pada tanggal 27 November 2015 pukul 06:00 WIB http://elshinta.com/info/8603 tentang polling pilwakot kota Semarang 2015 diakses pada tanggal 27 November 2015 pukul 06:30 WIB. 


\section{Terima kasih kepada Mitra Bestari}

Berkaitan dengan diterbitkannya Jurnal Ilmiah Komunikasi Makna Fakultas Ilmu Komunikasi Universitas Islam Sultan Agung (UNISSULA) Semarang, maka kami menghaturkan banyak terima kasih kepada para Mitra Bestari yang telah berkenan membantu proses penyuntingan artikel ilmiah Makna sampai layak untuk dipublikasikan. Beberapa Mitra Bestari yang terlibat dalam proses penyuntingan :

1. Prof. Deddy Mulyana, MA., Ph.D dari Universitas Padjajaran (UNPAD) Bandung

2. Dr. Turnomo Rahardjo dari Universitas Diponegoro (UNDIP)

3. Dr. Sunarto dari Universitas Diponegoro (UNDIP)

4. Dra. Prahastiwi, Ph.D dari Universitas Sebelas Maret Surakarta (UNS) 